TEMPORARY MIGRATION AND SKILL UPGRADING: EVIDENCE FROM MEXICAN MIGRANTS

Steffen Reinhold and Kevin Thom 


\title{
Temporary Migration and Skill Upgrading: Evidence from Mexican Migrants*
}

\author{
Steffen Reinhold \\ MEA, University of Mannheim
}

\author{
Kevin Thom \\ New York University
}

June 19, 2009

\begin{abstract}
This paper explores the extent to which temporary Mexican migrants upgrade their skills while working in the United States. The vast majority of the migration that we observe is undertaken without documents. In contrast to Lacuesta (2006), we find that labor market performance in Mexico is positively related to one's accumulated migration experience in the United States. Self-selection of high-skilled individuals into migration does not drive this result. We also investigate the possible mechanisms by which migration experience might improve earnings in Mexico. We find support for the notion that migration experience improves labor market outcomes by improving occupation specific skills rather than by inducing higher rates of occupational mobility or entrepreneurship.
\end{abstract}

\section{JEL CLASSIFICATION: F22, J61}

Keywords: return migration, skill-upgrading, wage premium, Mexico

${ }^{*}$ We would like to thank Robert Moffitt, Tiemen Woutersen, Martin Salm, Govert Bijwaard, and Christina Gathmann for helpful comments. Also, we are grateful for the feedback offered by seminar participants at the University of Mannheim, the meetings of the International Economic Association, and the meetings of the Society of Labor Economists. Corresponding Address: Kevin Thom - Department of Economics - 19 W. 4th Street 6th Floor - New York, NY 10012. E-mail: kevin.thom@nyu.edu 


\section{Introduction}

A large and growing literature explores the benefits of out-migration for migrant-sending countries. In this paper, we investigate one of the possible channels by which developing countries may gain from out-migration. Many migrants eventually return to their home countries, and they may return with extra skills acquired through contact with the workers, capital, and technology of a foreign country. We investigate the extent of skill-upgrading by using a sample of Mexican workers with and without experience as workers in the United States. We control for the possible endogeneity of both the migration and return decisions. In addition, we also test for the plausibility of some potential mechanisms by which migration experience might affect success in the Mexican labor market.

Much of the literature on the benefits of out-migration for developing countries focuses on the role of remittances in raising standards of living for non-migrants and directly financing investment in physical and human capital. 1 n New studies also highlight other channels by which migration can benefit sending countries. As Docquier and Rapoport (forthcoming) discuss in a recent review of the literature on skilled migration, the possibility of future migration to a country with higher returns to human capital may induce natives of the sending country to invest more heavily in education, raising the local stock of human capital. Additionally, skilled individuals may become employed in the relatively more productive Research and Development sectors of receiving countries, producing and disseminating technology which may benefit the source country.

However, if migration is temporary, there exist additional linkages between out-migration and development. Migrants working in a developed receiving country may come into contact with more advanced production technologies, or they may work with more highly skilled workers. Such interactions may allow workers to upgrade their skills and earn higher wages

\footnotetext{
1 Rapoport and Docquier (2007) provide a broad survey of contemporary research in this area.
} 
upon returning to their home countries. Indeed, Dustmann and Weiss (2007) and Borjas and Bratsberg (1996) consider models of temporary migration in which skill upgrading may be an important motivation for return migration. As Dos Santos and Postel-Vinay (2003) argue, this effect of temporary migration may help to expand a source country's human capital stock and increase its rate of economic growth.

The existing empirical studies of temporary migration and skill-upgrading focus primarily on the European experience. De Coulon and Piracha (2005) analyze data from Albanian workers and find that the return migrants in their sample are negatively selected on the basis of pre-migration earnings, but experience a wage premium as a result of temporary migration. Iara (2006) also finds evidence of a wage premium using data from workers in Central and Eastern Europe. Iara's results indicate that workers with some migration experience in Western Europe earn approximately one-third more than they would had they never migrated. Using Hungarian data, Co et al. (2000) conclude that time spent abroad improves the labor market performance of female migrants, but not the performance of male migrants.

While the high volume of recent intra-European migration certainly justifies the attention paid to temporary migration and skill upgrading in Europe, relatively little research assesses the skill upgrading hypothesis in the context of Mexican migration to the United States. Beginning with the Bracero guestworker program (1942-1964), Mexico-US migration has been distinguished by a high propensity for return migration (Massey et al., 2003). Although much has been written on the development impact of migrants' remittances in Mexicd 2 , the possibility of skill upgrading on the part of return migrants has received relatively little attention. Using data from the 2000 Mexican census, Lacuesta (2006) finds that migrants tend to earn about 7-10 percent higher wages than non-migrants upon returning. However,

\footnotetext{
${ }^{2}$ For examples, see Woodruff and Zenteno $(2007)$ and Durand et al. (1996).
} 
he attributes much of this to the selectivity of migrants and not to any skills that migrants may have acquired in the United States. Lacuesta's results indicate that the gap between the Mexican wages of return migrants and non-migrants does not appear to increase as the length-of-stay in the United States increases. These results stand in contrast to those of Zahniser (1999). Using data from the Mexican Migrant Project (MMP), Zahniser does find evidence that time spent in the United States increases the earnings of migrants who return to Mexico. However, Zahniser uses an earlier, more limited release of the MMP data.

In this paper, we re-examine the extent of skill upgrading in the Mexico-US case using income data on migrants and non-migrants from the Mexican Migrant Project. We exploit the rich life histories of household heads collected by the MMP to construct a measurement of migration experience over the course of a household head's entire observed lifetime. We estimate a sample selection model that uses shocks to labor markets in the United States as instruments for endogenous measures of migration experience. We find that the accumulation of migration experience in the United States is associated with significantly higher earnings in Mexico, and that selection does not drive this finding. We contend that the continuous measurement of lifetime migration experience permitted by the MMP data more accurately tracks lifetime migration behavior than other data, and that this may explain the differences between our findings and those in other studies.

We also try to determine which mechanisms explain the positive effect of migration experience on earnings. Some studies, such as Dustmann and Kirchkamp (2002), suggest that temporary migration may increase the earnings of return migrants by financing entrepreneurial activity or enabling occupational change. We find that these channels play a minor role in explaining the Mexican migration premium. However, we do find that migrants tend to gain the most from U.S. experience when their occupations abroad match their occupations in Mexico, suggesting that that time spent abroad might help directly to 
upgrade skills. We also find suggestive evidence that the labor market return to legal migration experience may be higher than that of illegal migration experience, although the lack of additional instruments prevents us from estimating a sample selection model in which these are treated as separate endogenous regressors.

The paper proceeds as follows. Section 2 describes the MMP data and provides some descriptive statistics from the sample used in this study. Section 3 describes the empirical

model and discusses our instruments. Section 4 presents estimation results, and Section 5 explores the possible mechanisms that might explain the return to migration experience.

\section{Data and Descriptive Statistics}

The data collected by the MMP present researchers with the unique opportunity to observe earnings for particular individuals along with detailed migration histories. Each year, the MMP selects a group of Mexican communities and surveys a random sample of the households in each location. After surveying a particular community in Mexico, the MMP also attempts to locate individuals from that community who are currently residing in the United States, forming a sample that includes non-migrants, migrants who have returned to Mexico, and migrants who are still in the US. The MMP survey collects demographic and economic data on households and individuals, with a particular emphasis on migration experience. The survey also requests a detailed, self-reported life history from household heads recording some economic, demographic, and migration variables for every year in their lives. These life histories record whether or not an individual migrated in a given year, how many months an individual spent in the U.S., and what documents, if any, were used to migrate. The MMP data permit us to construct a direct measurement of Mexican labor market experience, rather than approximating it using age and education. 
Our sample consists of male household heads aged 15-65 at the time of the MMP interview who were surveyed during the years 1987-2007. The MMP survey asks each household head to report his or her income at the time of the survey. Although this variable is reported at different rates (e.g. weekly, biweekly, monthly), we convert all income measures to monthly values throughout the paper. After dropping observations in the top centile of the earnings distribution for each year and a small number of observations with missing information on earnings, our full sample includes 8070 individuals interviewed while in Mexico, and 1339 individuals interviewed in the United States. The sample design is such that in each survey year, the MMP samples about five different communities. This implies that in the empirical models that follow, a full set of community fixed effects will subsume year effects, making price deflation unnecessary when working with logs. However, for the descriptive statistics and throughout the paper, we deflate earnings using CPI indices for Mexico and the US (2000 base year) taken from the IMF's International Financial Statistics series.

We present summary statistics of log earnings and important characteristics of migrants and non-migrants in Table1. The first column displays these statistics for the full sample of individuals interviewed while in Mexico. This includes non-migrants and return migrants, but excludes individuals who have migrated but have not returned to Mexico. The average age for the full Mexican sample is about 41.5, and the average level of education is about 6.7 years. Most individuals are married (89.4\%). A substantial fraction of individuals have some experience migrating to the U.S. (29.0\%), with an average migration experience of about 1 year. It should be noted here that the vast majority of migration experience observed in the sample represents undocumented or illegal migration. While approximately $90 \%$ of the return migrants in the sample report at least some undocumented experience, only about 25\% report any legal migration experience. The average person in the sample has accumulated around 0.71 years of undocumented migration experience and 0.25 years of legal experience. 
The second and third columns of Table 1 present summary statistics for the return migrants and non-migrants in the sample, respectively. Raw averages alone do not suggest that migrants earn more than non-migrants. Indeed, the average non-migrant earns approximately $1.6 \%$ more than the average migrant in sample. However, the average non-migrant has about 1.4 more years of education than the average migrant, and around four more years of experience in the Mexican labor market (the MexExp variable). Given the non-trivial advantages that non-migrants hold in education and Mexican labor market experience, it may be somewhat surprising that they do not enjoy a larger earnings gap relative to migrants.

Finally, in the fourth column of Table 1 we consider the sample of individuals who have migrated but have not returned to Mexico by the time of the interview. We do not observe current Mexican earnings for these individuals, but it is useful to investigate this group's demographic characteristics, especially since we may be concerned that the return migrants we observe in our Mexican sample may be a select subset of all migrants. The fourth column of Table 1 indicates that these non-returning migrants appear to be younger than the other groups with an average age that is a little more than four years less than than the average in the entire Mexican sample. The average educational attainment of this group is quite close to the average for the Mexican sample, but marriage appears to be slightly less common among non-returning migrants, perhaps reflecting a decision to wait until one returns to Mexico to settle down and marry. The most noteworthy difference between non-return migrants and other groups is that the non-return migrants have significantly less Mexican labor market experience, with an average of about 10 years as opposed to an average near 24 years for the entire Mexican sample. Two factors help explain this difference. First, the non-returning migrants have much more migration experience in the US (an average of about 11.3 years as opposed to 3.3 years for return migrants). Presumably the combination of relative youth and this greater migration experience has limited their opportunities to acquire labor market 
experience in Mexico.

\section{Empirical Model and Estimation Strategy}

To test whether or not migration experience is associated with skill acquisition, we measure the return to accumulated migration in a standard human capital production function similar to that of Mincer (1974). We can imagine simply augmenting a familiar log earnings equation to include a vector of variables, $M_{i}$, measuring individual $i$ 's accumulated migration experience up until the time of the survey. Such a model would take the form:

$$
w_{i}^{*}=M_{i} \beta_{m}+X_{i} \beta_{x}+C_{i} \beta_{c}+\varepsilon_{i}
$$

Where $w_{i}^{*}$ represents the log of monthly earnings in Mexico, $M_{i}$ is a vector that may include multiple measures of migration experience, $X_{i}$ is a vector of economic and demographic variables including accumulated Mexican labor market experience $\left(M e x E x p_{i}\right)$ the square of this experience variable, and controls for years of educational attainment and marriage. The vector $C_{i}$ contains a series of dummy variables controlling for community of origin, and since each community is surveyed only in one particular year, this vector also subsumes annual fixed effects.

Two potential problems emerge in trying to estimate the coefficients $\beta_{m}$ related to migration experience in Equation 1. First, the migration experience variables may be correlated with the error term, $\varepsilon_{i}$, so that $E\left(M_{i} \varepsilon_{i}\right) \neq 0$. The accumulation of migration experience is the result of economic decisions. Individuals choose levels of $M_{i}$ based on the monetary and non-monetary costs and returns of migration, and their decisions may be constrained by limited access to credit for the financing of migration costs. Unobserved heterogeneity in the costs and returns of benefits of migration, as well credit availability will influence the amount 
of $M_{i}$ that individuals accumulate, and each of these could be correlated with the error term $\varepsilon_{i}$ in the earnings equation. For example, ambitious or driven individuals might face lower non-monetary costs of migration, causing them to accumulate more migration experience than others, while they also receive higher draws of $\varepsilon_{i}$, and thus experience higher earnings. If this is the case, then OLS estimates of $\beta_{m}$ will be biased upwards.

A second potential problem related to the OLS estimation of Equation 1 involves the selectivity of the observed sample. We only observe Mexican earnings for individuals who are present in Mexico at the time of the survey, so if an individual migrated and did not return to their community by the date of the survey, we do not observe their potential Mexican earnings. Let the indicator $S_{i}$ take the value 1 if individual $i$ is surveyed in Mexico, and 0 otherwise. If $E\left(\varepsilon_{i} \mid S_{i}=1\right)$ depends on the regressors included in Equation 1, then the OLS parameters estimates will be biased.

Let $S_{i}^{*}$ represent a latent variable related to whether or not individual $i$ is present in Mexico at the time of the MMP survey. So far we have described $M_{i}$ as being one of a number of measures of migration experience. To fix ideas, we assume here that $M_{i}$ measures the number of years of migration experience that individual $i$ has accumulated. We represent $M_{i}$ as a censored random variable, where we observe migration experience only if the latent variable $M_{i}^{*}$ is positive. Our basic empirical model consists of the following system:

$$
\begin{aligned}
w_{i}^{*} & =M_{i} \beta_{m}+X_{i} \beta_{x}+C_{i} \beta_{c}+\varepsilon_{1 i} \\
S_{i}^{*} & =z_{i} \gamma_{z}+X_{i} \gamma_{x}+C_{i} \gamma_{c}+\varepsilon_{2 i} \\
M_{i}^{*} & =z_{i} \gamma_{z}+X_{i} \gamma_{x}+C_{i} \gamma_{c}+\varepsilon_{3 i}
\end{aligned}
$$


where we observe

$$
\begin{aligned}
S_{i} & = \begin{cases}1 & \text { if } S^{*}>0 \\
0 & \text { otherwise }\end{cases} \\
M_{i} & = \begin{cases}M_{i} & \text { if } M^{*}>0 \\
0 & \text { otherwise }\end{cases} \\
w_{i} & = \begin{cases}w_{i}^{*} & \text { if } S^{*}>0 \\
\text { unobserved } & \text { otherwise. }\end{cases}
\end{aligned}
$$

Here $X_{i}$, and $C_{i}$ are as defined above, and $z_{i}$ is a vector consisting of extra regressors affecting both lifetime migration experience and one's location during the survey year. Equations 3 and 4 are linear, reduced-form approximations of a more complicated stochastic process determining an individual's location at the time of the survey, $S_{i}$, and an individual's accumulated migration experience, $M_{i}$. We will discuss the dynamic process approximated by these equations later in our discussion of instruments.

Although we will discuss this in more detail when we introduce our specific instruments, we can think of the instruments $z_{i}$ as a vector of variables measuring exogenous shifts in the incentives to migrate or return at various stages in the individual's life. We assume that the error vector $\left\{\varepsilon_{1 i}, \varepsilon_{2 i}, \varepsilon_{3 i}\right\}$ in the above system is distributed according to a trivariate normal distribution, and that the earnings and selection errors follow the marginal distribution: $\left\{\varepsilon_{1 i}, \varepsilon_{2 i}\right\} \sim N([0,0], \Sigma)$ where $\Sigma=\left[\begin{array}{cc}\sigma^{2} & \rho \\ & \\ \rho & 1\end{array}\right]$.

We have assumed that the errors in Equations 2, 4 are normally distributed largely out of convenience. With instruments $z_{i}$ related to both migration experience and selection, the model is identified without the assumption of a specific distribution for the errors. In principle we could use semiparametric methods to estimate the parameters of interest in 
Equation 2. However, we will use the normality assumption in the estimation here to ease the computational burden of estimation. We may be particularly concerned about the assumption of normality for migration experience. As a rough check for the plausibility of this assumption, Figure 1 plots the distribution of total years of U.S. migration experience for the migrants in the sample. The distribution looks similar to the right tail of a normal distribution. However, we take the assumption of normality here simply as an approximation to a more complex stochastic process determining the accumulation of migration experience.

We estimate the parameters of Equations 2,3 using the two-step procedure developed by Heckman (1974). As Newey and McFadden (1994) demonstrate, a two-step estimator of this kind can be recast as a method of moments estimator. We follow this approach here, with the moment conditions modified to account incorporate instruments not included in the main earnings equation $3^{3}$ The vector of instruments $z_{i}$ is assumed to be correlated with the endogenous migration experience variables in the $M_{i}$ vector, but to satisfy the exogeneity conditions $E\left(z_{i} \varepsilon_{1 i}\right)=0$. We will discuss our choice of extra instruments $z_{i}$ below, but first we outline the moment conditions we use in the estimation.

Let $Z_{i}^{s}$ refer to the full set of exogenous regressors in the model that enter the selection equation, so that $Z_{i}^{s}=\left[z_{i} X_{i} C_{i}\right]$, and let $\gamma$ denote the full parameter vector for this equation: $\gamma^{\prime}=\left[\gamma_{z} \gamma_{x} \gamma_{c}\right]$. The probability that an individual is observed in Mexico is then given by $\operatorname{Prob}\left(S_{i}=1 \mid Z^{s}\right)=\Phi\left(Z_{i}^{s} \gamma\right)$, where $\Phi(\cdot)$ is the standard normal cdf. Our first set of moment conditions are the elements of the score vector for the Maximum Likelihood estimator of the parameters in Equation 3 .

$$
\bar{m}^{1}(\widehat{\gamma})=\sum_{i} Z_{i}^{s \prime}\left[\left(S_{i}-\Phi\left(Z_{i}^{s} \widehat{\gamma}\right)\right) \frac{\phi\left(Z_{i}^{s} \widehat{\gamma}\right)}{\Phi\left(Z_{i}^{s} \widehat{\gamma}\right)\left(1-\Phi\left(Z_{i}^{s} \widehat{\gamma}\right)\right)}\right]=0
$$

\footnotetext{
${ }^{3}$ See Meijer and Wansbeek (2007) for a full exposition of the GMM implementation of the Heckman two-step model with endogenous regressors.
} 
The remaining moment conditions are based on the orthogonality of the exogenous variables and the errors in Equation 2,

$$
\bar{m}^{2}(\widehat{\beta}, \widehat{\gamma})=\sum_{i} Z_{i}^{w \prime} S_{i}\left(w_{i}-\tilde{X}_{i} \beta\right)
$$

Here $\tilde{X}_{i}=\left[M_{i} X_{i} C_{i} \widehat{\lambda_{i}}\right]$ and $\beta^{\prime}=\left[\begin{array}{llll}\beta_{m} & \beta_{x} & \beta_{c} & \rho\end{array}\right]$ represent the full set of regressors and parameters included in the earnings equation, with the Heckman lambda, $\widehat{\lambda}_{i}=\frac{\phi\left(Z_{i}^{s} \widehat{\gamma}\right)}{\Phi\left(Z_{i}^{s} \widehat{\gamma}\right)}$ being added as a regressor to control for $E\left(\varepsilon_{1 i} \mid S_{i}=1\right)$. The vector $Z_{i}^{w}=\left[\begin{array}{llll}z_{i} & X_{i} & C_{i} & \widehat{\lambda_{i}}\end{array}\right]$ is the complete set of instruments that are assumed to be exogenous to the error term in the earnings equation. We use the efficient two-step procedure of Hansen (1982) to estimate the parameters $[\gamma \beta]$ and calculate standard errors.

\subsection{Choice of Instruments}

We use labor market shocks in the United States during an individual's teenage years as instruments for migration experience. Although we do not specify a behavioral model here, the justification for a relationship between labor market shocks in the U.S. and the accumulation of migration experience is straightforward, and changes in U.S. labor demand have elsewhere been used as exogenous shifts in the incentives to migrate and stay abroad (for example, see Schnabl 2007). Simple static models often result in the condition that migration will only occur if the expected wage in the foreign country, net of costs, exceeds the expected wage in the home country. Furthermore, these models suggest that the incentive to migrate is monotonically increasing in the net expected wage gap between the two countries. Harris and Todaro (1970) offers the canonical version of such a model. However, even in more complicated dynamic models of migration, including those developed by Thom (2008), Bellemare (2007), and Colussi (2006), the incentive to migrate in any given period is increasing with 
the expected wage gap.

We claim that individuals who grow up during periods of better labor market conditions in the U.S. should form more positive expectations about the wage gap between the United States and Mexico as they update their beliefs about opportunities abroad. Higher expectations about the wage gap between the U.S. and Mexico are in turn expected to increase the migration experience that an individual accumulates. It is well documented that the propensity to migrate peaks during an individual's early twenties.4 This pattern is also confirmed in our data. Figure 2 displays the histogram of the age at which migrants in our total sample first migrated. Indeed, individuals in our sample appear to be most prone to migrating when they are around 20 years old. Thus, it seems reasonable to assume that information about labor market opportunities in the United States may be most influential in shaping expectations about future conditions in the U.S. during and slightly before these age ranges, as individuals start to make independent labor market and mobility choices.

Using instruments related to U.S. labor market shocks in one's teenage years, our source of identification for the effect of migration experience on earnings becomes the differences in the observed migration and earnings outcomes across different cohorts of Mexican workers. Consider two individuals, both sharing the same observable characteristics, such as age, education, and work experience. If one of these individuals was born into a cohort that lived through a more positive early sequence shocks in the United States labor market than the other, we would expect this individual to accumulate more lifetime migration experience since he or she lived through a period offering greater incentives to migrate. This is the source of exogenous variation in the incentives to migrate that we try to capture with our instruments.

By adopting this identification strategy, we are assuming that there do not exist inde-

\footnotetext{
${ }^{4}$ See Lucas (1997) on this trend among internal migrants in developing countries
} 
pendent cohort effects for earnings that might be correlated with the sequence of U.S. labor market shocks that each cohort lived through during its teenage years. We might worry that cohort effects could be very highly correlated with characteristics that vary or grow over time such as Mexican work experience. However, since our data come from multiple survey years, we observe individuals from the same cohort with different levels of these time-varying characteristics.

Another potential problem with our instruments could arise if there exist independent effects of age which are not summarized in our measures of work experience and education. In our specifications we do not include age because of the resulting problems of collinearity. Even after conditioning on experience and education, age could still be simultaneously correlated with earnings and with the U.S. labor market shocks, potentially invalidating our instruments. We checked for this possibility by including a function of age in the earnings equation resulting in very imprecise estimates of the effect of migration. While this robustness check remained inconclusive, the problem is again somewhat mitigated by the fact that we observe different individuals in multiple survey years. Persons of the same age could have experienced different U.S. labor market shocks depending on the year in which they were surveyed.

To create instruments that measure U.S. labor market shocks in different years of an individual's life, we use U.S. earnings data from the Current Population Survey. The sequence of shocks that we estimate reflects the labor market trends in the most important destination States for Mexican migrants. Three states dominate as U.S. destinations in our sample: California, Texas, and Illinois. These three states account for the destinations of over $80 \%$ of the person-years spent in the United States, and no other state comes close to matching the individual contributions of these three states over the time period that we consider. Since migrants are primarily going to California, Texas, and Illinois, shocks to the 
labor markets in these states should be particularly important in altering the incentives of Mexican individuals to migrate or stay in the United States. We aggregate the information contained in these three sequences into one index of labor market conditions in the parts of the U.S. that are most relevant for the migrants in our sample.

To measure shocks to the California, Texas, and Illinois labor markets for a given year, we gather annual labor income data on full-time male workers, aged 15-64 years, from the March Current Population Survey for the years 1964-2000. Using this data, we estimate a log labor market income equation of the following form:

$$
\begin{aligned}
& w_{i t}^{u s}=\beta_{0}+\beta_{1} X_{i}+\beta_{2} \mu_{t}+\beta_{3} \text { Calif }_{i}+\beta_{4} \text { Texas }_{i}+\beta_{5} \text { Illinois }_{i} \\
& +\beta_{6} \text { Calif } \times \mu_{t}+\beta_{7} \text { Texas } \times \mu_{t}+\beta_{8} \text { Illinois } \times \mu_{t}+\varepsilon_{i}
\end{aligned}
$$

Here $X_{i}$ is a vector of individual characteristics including potential experience, the square of potential experience, educational attainment, and dummy variables indicating marriage and inclusion in a non-white racial group. The vector $\mu_{t}$ is a series of dummy variables indicating survey years, and Calif $f_{i}$, Texas $_{i}$, and Illinois $_{i}$ are dummy variables indicating residence in either California, Texas, or Illinois, respectively. The interaction vectors Calif $\times \mu_{t}$, Texas $\times \mu_{t}$, and Illinois $\times \mu_{t}$ are added to pick up yearly shocks unique to California, Texas, and Illinois.

To measure the shocks to the U.S. labor markets, define Calif Shock $k_{t}=\widehat{\beta}_{3}+\left(\widehat{\beta}_{2}+\widehat{\beta}_{6}\right) d^{t}$, where $d^{t}$ is a vector that indicates year $t$. Similarly, define TexasShock $k_{t} \widehat{\beta}_{4}+\left(\widehat{\beta}_{2}+\widehat{\beta}_{7}\right) d^{t}$ and IllinoisShock $=\widehat{\beta}_{5}+\left(\widehat{\beta}_{2}+\widehat{\beta}_{8}\right) d^{t}$ for Texas and Illinois, respectively. To filter out some of the excess noise in these labor market shocks, we create smoothed shocks $\overline{\text { Calif Shock }}_{t}$ , $\overline{\text { TexasShock }}_{t}$, and $\overline{\text { IllinoisShock }}_{t}$ for a given year $t$ by taking the average of the basic 
labor market shocks over the years $t-1, t$, and $t+1$. Figure 3 graphically summarizes the time-path of these smoothed labor market shocks.

Let $t_{i a}$ refer to the year in which individual $i$ is $a$ years of age. We use the sequences of smoothed state specific labor market shocks estimated above to create a single index of U.S. economic conditions, USShock $k_{t_{i a}}$, that aggregates the state specific shocks in year $t_{i a}$. State shocks are weighted so as to reflect the importance of each state to the flow of Mexican migrants. For example, the weight for California, $\omega^{C}$ is found by adding up the total number of person-years in which we observe anyone in our data set living in California, and dividing by the total number of person-years for which we observe someone living in California, Texas, or Illinois. The weights found in this manner are $\omega^{C}=0.703 \omega^{T X}=0.152$, and $\omega^{I L}=0.145$. The USShock $t_{i a}$ terms formed with these weights are:

$$
\text { USShock }_{t_{i a}}=\omega^{C} \overline{\text { CalifShock }}_{t_{i a}}+\omega^{T X} \overline{\text { TexasShock }}_{t_{i a}}+\omega^{I L} \overline{\text { IllinoisShock }}_{t_{i a}}
$$

We take as our instruments the vector $\left[U_{S S h o c k_{t_{i, 15}}} U S S h o c k_{i t_{i, 17}} U S S h o c k_{i t_{i, 19}}\right]$. Our instruments are thus measures of U.S. labor market shocks for the years during which an individual was aged 15, 17, and 19 years. Since the smoothed shocks use information on labor market conditions the year before and year after a particular year $t$, these shocks thus aggregate information on the entire sequence of labor market shocks that an individual experienced between the ages 14-20. Since the late teens and early twenties are the age ranges in which individuals are most prone to first migrating, our instruments measure U.S. labor market conditions at precisely the time when individuals should start becoming sensitive to such information. 


\section{Estimation Results}

\subsection{OLS Specifications}

As a first step, we estimate Equation 2 by OLS, both to offer a baseline set of results to which we can compare the selection model estimates, and to further describe the raw patterns in the data. In Table 2 we first present basic OLS results using different measures of migration experience in the $M_{i}$ vector. For all specifications, we report robust standard errors. In the first column, we present results for a basic specification without variables summarizing US migration experience. We find a small but statistically significant return to Mexican labor market experience which declines with the amount of experience, but is about .03\% per year at 20 years of experience. We estimate the return to education to be about $5.7 \%$ for each additional year of schooling. There is a substantial marriage premium of about $8.1 \%$ for the earnings of married men.

In the next column we include a dummy for any migration experience to our basic specification. None of the coefficient estimates from the first specification have changed substantially. The coefficient on the dummy for any migration experience suggests a migration premium of about $1.7 \%$, but this is not statistically significant.

In the third column we consider the number of years the individual has spent working in the United States as our measure of migration experience, rather than the dummy variable. As before, the inclusion of this regressor does not significantly alter the coefficients on the other covariates. Since US experience is measured in years the results are directly comparable to the returns to education and experience. The coefficient on US experience is 0.022 and statistically significant at the $1 \%$ level. These point estimates therefore suggest that the marginal effect of US migration experience on Mexican earnings is more than twice as large as the marginal effect of Mexican experience on Mexican earnings. However, the return to 
one year of education is still much larger than the return to either US or Mexican experience.

\subsection{Return to Short Migration}

We now consider an alternate set of migration variables in the $M_{i}$ vector consisting of dummy variables indicating different levels of migration experience: no migration, migration of less than one year, 1-2 years, 2-3 years, and more than 3 years of migration experience. We do this to generate a set of results comparable to those of Lacuesta (2006), who argues that the inclusion of such variables as regressors in a wage equation can allow for the separate identification of the direction of selectivity into migration and the presence of skill-upgrading. Lacuesta argues that skill-upgrading should be a timely process, and thus we can assume that individuals who return after very short stints abroad, perhaps less than a year, have not had time to acquire the same level of skills as someone staying abroad for two or three years. Thus, if we include a set of dummy variables capturing the effects described above, we can detect skill-upgrading if the coefficients on the dummy variables for successively higher levels of experience get larger and larger. On the other hand, if we observe that individuals with migration experience levels of less than a year are reaping the same migration premium as indiviudals who have stayed for several years, then this could be interpreted as evidence that migrants are positively selected, accounting for the higher Mexican earnings of migrants, and higher levels of migration experience do not seem to add to Mexican earnings through some skill-upgrading channel. Indeed, Lacuesta does not find a significant wage premium for indiviudals in experience categories beyond the "less than one year" category, and he concludes that such a result suggests the absence of skill-upgrading.

In columns 4 and 5 of Table 2 we replicate Lacuesta's approach using our data. Our results reveal that migrant workers spending only a short time in the United States do not experience an earnings premium. Indeed, there appears to be a small penalty. There is only 
a statistically significant wage premium for individuals staying longer than 3 years. In the second column, we include the linear term in US migration experience and the dummy for less than one year of experience. Again, in this specification, individuals staying less than one year do not experience an earnings premium, and we find almost the same return to migration experience $(2.1 \%)$ as in the basic OLS specification using the entire sample. This is consistent with the idea that skill-upgrading is largely responsible for the positive association between US migration experience and earnings in Mexico. We explain the differences between our results and those found in Lacuesta $(2006)$ as stemming from some of the limitations of his data. The Mexican Census data do not reveal the life experience of migration but only migration experience accumulated during the last five years, which induces a right-censoring of this important variable. This type of censoring will incorrectly classify as non-migrants older workers who accumulated migration experience in their youth.

\subsection{Results from the Selection Model}

Table 3 presents parameter estimates for all equations of the full selection model in Equations 2-3. We use three instruments to estimate the equation: USShock ${ }_{i t_{15}} U_{S S h o c k_{i t_{17}}}$ USShock $k_{i t_{19}}$. In the first column of Table 3, we report results for the wage equation. We estimate the return to US experience to be large and statistically significant. A one year increase in US migration experience is estimated to increase monthly labor income by about 9.9\%. Neither the coefficient on MexExp nor the coefficient on the square of this variable are found to be statistically significant. However, as before, we find a positive and significant return to education of about $6.1 \%$ per year, but now we find a lower marriage premium of about $5.0 \%$. The coefficient on the $\widehat{\lambda}$ selection term is negative $(-0.328)$ but statistically

insignificant. The negative coefficient on $\widehat{\lambda}$ would suggest that selection into the sample is negatively correlated with earnings. We also fail to reject the null hypothesis in Hansen's J 
test for the overidentifying restrictions, offering some limited support for the exogeneity of our instruments.

To assess the strength of the instruments in explaining migration experience when the selection term is included as a regressor in our various specifications, the second column presents the equation for US migration years. The instruments perform well even with the inclusion of the selection term, although the estimated coefficient on the USShock ${ }_{i t_{17}}$ is negative for this specification. The F-statistic for the instruments is 47.95, and we do not have a weak instrument:5 problem even after including the Heckman lambda which is also a function of the instruments. In the third column, we also present estimation results for the selection equation. The instruments have the expected sign. After experiencing positive US labor market shocks in the youth, individuals are less likely to be in Mexico at the time of the survey.

Our results do not suggest that sample selection is driving the positive relationship between US migration experience and earnings in Mexico. After correcting for the endogeneity of US migration experience, we find a much larger return to migration experience than the one found in the OLS specifications. This is consistent with the notion that individuals with lower levels of unobservable skill or ability may be the ones accumulating more migration experience in our sample, thus biasing the estimated effect of migration experience downwards in OLS regressions. Notice that we reach the same conclusion from the results in table 2 when we replicate the regressions from Lacuesta (2006).

\subsection{Robustness Check}

One possible problem with the specifications considered here is that they pool together data on individuals observed over the long interval 1987-2007. We may be worried that the model's

\footnotetext{
${ }^{5}$ See Stock et al. (2002) for a survey of the literature on weak instruments.
} 
true coefficients may have changed over time. As a robustness check and as a way to explore possible changes in the return to U.S. experience, we split the sample into two groups: those interviewed during 1987-1996, and those interviewed during 1997-2007. Table 4 reports the results when the full selection model is estimated separately for each group, with total years of migration experience being the endogenous regressor. We estimated a return to total U.S. migration experience of $11.7 \%$ and $9.1 \%$ for the two samples, respectively. It is reassuring that we get rather similar estimates using the two different samples. However, using the 1997-2007 sample, we are able to reject the null hypothesis of Hansen's J test, which raises concerns about the possibility that the instruments may be correlated with the earnings error term.

\section{Explaining the Return to Migration}

The results of the previous section suggest that time spent in the United States is rewarded in the Mexican labor market, and that the rate of return to one year in the United States may be substantially higher than the return to one year spent in the Mexican labor market. But what is driving this result? Our main hypothesis has been that individuals learn skills in the United States that are transferable to the Mexican labor market and that the high return to migration experience reflects the relative scarcity of these skills compared to skills acquired while working in Mexico. However, the extent of skill-upgrading could depend on factors

such as the legal status of a migrant. For example, if undocumented workers are relegated to sectors of the economy offering fewer opportunities for learning, one would expect to observe lower returns to undocumented experience.

We also consider two possible mechanisms outside of skill-upgrading that might account for a positive return to migration experience: occupational change and entrepreneurial activ- 
ity. Migrants in the United States may be exposed to occupations in the United States that differ from their pre-migration occupations in Mexico. Such experience may cause return migrants to move into these new occupations in Mexico. If these new occupations are associated with higher earnings in Mexico, then this mechanism could explain the high return to U.S. experience found in the data. It could also be the case that migration allows individuals to overcome credit constraints and raise the capital necessary to start their own business. If this is common, then the increase in earnings following migration could reflect the higher wages that follow business ownership, rather than any skill-upgrading taking place in the United States.

The MMP data do allow us to track legal status during migration, occupation and business ownership over the course of an individual's life. In theory, the competing channels through which migration influences Mexican s could be de-tangled by augmenting the earnings equation in our selection model to include legal status, occupation and business ownership. However, since legal status, occupation and business ownership are all the result of economic decisions and are thus endogenous, one could not properly insert these variables in the selection model without a large set of additional instruments. Lacking instruments for all endogenous regressors, we examine some rough features of the data in this section to explore the plausibility of each of these explanations for the positive influence of migration experience on earnings.

The first column Table 8 reports the results for an OLS regression of labor income when years of documented experience and undocumented experience enter as separate regressors. We find a higher return $(3.3 \%)$ for documented experience than for experience as undocumented worker (1.6\%). However, we only marginally reject the null hypothesis of equal coefficients. The relatively small number of legal migrants in the sample likely contribute to this imprecision. Overall, it seems that both documented and undocumented work ex- 
perience are associated with very high premiums which are much larger than the premium associated with Mexican labor market experiences.

To investigate whether the return to migration experience might reflect a change in occupational choice after return migration, we divide occupation into 7 categories: Agriculture, Manufacturing - Supervisors, Manufacturing-Skilled, Manufacturing-Operators, ManufacturingUnskilled, Service Sector, and Other. Table 5 reports the fractions of the sample working in these various occupations during the survey year. Relative to non-migrants, return migrants are more likely to work in agriculture, a sector with relatively low wages. If more labor market experience in the US helps migrants to move to better paying sectors of the economy this factor could explain the earnings premium we have uncovered. To explore whether or not migration alters the distribution of occupations for return migrants, Tables 6 - 7 report the distribution of current occupations conditional on an individual's first occupation in Mexico, both for return migrants and non-migrants..$^{6}$ For example, the row labeled "Agriculture" in Table 6 considers return migrants who first worked in Agriculture in Mexico, and the columns of that row give the percentages of these workers engaged in various occupations at the time of the survey. So $52.74 \%$ of migrants whose first Mexican occupation was in agriculture are still working in that sector, while $14.01 \%$ are now working in skilled manufacturing jobs. We compare these transition rates for migrants with those of non-migrants in Table 7. We find that the transition rates for migrants and non-migrants look quite similar. One striking difference is that migrants are more likely than non-migrants to change their occupational category from Other to either Skilled Manufacturing or Agriculture. Also, migrants who start out as Skilled or Unskilled Manufacturing workers appear more likely than non-migrants to transition into Agriculture. Since agricultural workers tend to receive lower wages, this does not seem to offer an explanation for the return to U.S. migration

\footnotetext{
${ }^{6}$ In most cases, individuals start working in Mexico before their first trip to the United States.
} 
experience. However, it could be the case that migration allows return migrants to purchase agricultural land and thus become farm owners as opposed to hired agricultural labor. Overall, the data do not appear to support the notion that the return to migration is explained by occupational transitions.

It could be the case that return migrants use their savings from the US to start a business Dustmann and Kirchkamp (2002). If the reported labor income of these return-migrants includes business income, then the higher return to US experience would reflect the influence of migration on rates of entrepreneurship. In Table 5, we find some supportive evidence for the notion that migrants become entrepreneurs after returning from their migration trips from the US. Whereas before migration only $6.7 \%$ of return migrants own their businesses, around $31 \%$ of return migrants are business owners at the time of survey compared to $25.7 \%$ business ownership rates in the full Mexican sample. This surely reflects the effect of age, but we cannot exclude the possibility that migration experience increases business ownership rates.

In the second column of Table 8 we present the results for labor income regressions that include migration experience, business ownership dummies, and occupational status dummies as regressors. While we do find substantial premia to working in certain sectors or owning a business, the coefficient on U.S. migration experience virtually identical to the coefficient estimated in column 5 of Table 2. Thus, it seems unlikely that US migration experience raises earnings by helping migrants to move to better occupations or start a business.

Finally, to further test for the plausibility of the skill-upgrading hypothesis, we define a new variable "Relevant US Experience," which measures the number of years that an individual has worked in an occupation in the US that matches their current occupation in Mexico. We may be concerned if job experiences in the U.S. change one's occupational choice 
in Mexico, but we have found earlier that these transitions do not seem to be much larger for migrants compared to non-migrants. Thus, the return to Relevant Experience could better measure the extent of skill upgrading within a given occupation. In Table 8 we include this variable in the OLS regressions (columns 3 and 4) and find that the coefficient on Relevant US Experience is twice as large as the OLS coefficient on any US experience and statistically significant. If we include both a total measure of US migration experience and Relevant Experience the coefficient on Relevant Experience is found to be statistically significant, and more than four times as large as the coefficient on total US migration experience (columns 3 and 4). Thus, a promising explanation for our findings may be that migrants experience higher earnings due to occupation-specific skills that they learn while working in the United States.

\section{Conclusion}

In this essay we investigate whether migrants upgrade their skills during their stay abroad, and whether there are differences between documented and undocumented workers. We find that the level of an individual's U.S. migration experience is positively related to that individual's earnings upon returning to Mexico, and that the return to a year of migration experience is substantially larger than the return to a year of Mexican labor market experience. We obtain our results by estimating a sample selection model that accommodates endogenous regressors, and we use variables related to shocks to labor markets in the United States as instruments for accumulated migration experience. Overall, our findings support the skill-upgrading hypothesis, and do not suggest that migration increases earnings by increasing entrepreneurship or occupational mobility. 


\section{$7 \quad$ Tables and Figures}

Table 1: Summary Statistics of Important Variables for Different Sub-samples

\begin{tabular}{|c|c|c|c|c|}
\hline & \multicolumn{3}{|c|}{ Mexican Sample } & \multirow{2}{*}{$\begin{array}{l}\text { US Sample } \\
\text { Non-Return } \\
\text { Migrants }\end{array}$} \\
\hline & $\begin{array}{l}\text { Total Mexican } \\
\text { Sample }\end{array}$ & $\begin{array}{l}\text { Return } \\
\text { Migrants }\end{array}$ & Non-Migrants & \\
\hline Log Earnings (Deflated) & $\begin{array}{l}14.825 \\
(0.755)\end{array}$ & $\begin{array}{l}14.814 \\
(0.761)\end{array}$ & $\begin{array}{l}14.830 \\
(0.752)\end{array}$ & \\
\hline Age & $\begin{array}{l}41.532 \\
(11.370)\end{array}$ & $\begin{array}{l}41.760 \\
(11.216)\end{array}$ & $\begin{array}{l}41.439 \\
(11.432)\end{array}$ & $\begin{array}{l}37.409 \\
(10.173)\end{array}$ \\
\hline Education (years) & $\begin{array}{l}6.685 \\
(4.692)\end{array}$ & $\begin{array}{l}5.684 \\
(4.016)\end{array}$ & $\begin{array}{l}7.093 \\
(4.883)\end{array}$ & $\begin{array}{l}6.757 \\
(3.719)\end{array}$ \\
\hline Married $^{b}$ & $\begin{array}{l}0.894 \\
(0.307)\end{array}$ & $\begin{array}{l}0.930 \\
(0.255)\end{array}$ & $\begin{array}{l}0.880 \\
(0.325)\end{array}$ & $\begin{array}{l}0.857 \\
(0.351)\end{array}$ \\
\hline MexExp & $\begin{array}{l}24.392 \\
(12.076)\end{array}$ & $\begin{array}{l}21.809 \\
(11.838)\end{array}$ & $\begin{array}{l}25.446 \\
(12.014)\end{array}$ & $\begin{array}{l}9.978 \\
(9.130)\end{array}$ \\
\hline Ever Migrated ${ }^{b}$ & $\begin{array}{l}0.290 \\
(0.454)\end{array}$ & 1 & 0 & 1 \\
\hline US Migration Years & $\begin{array}{l}0.960 \\
(2.799) \\
\end{array}$ & $\begin{array}{l}3.311 \\
(4.387) \\
\end{array}$ & 0 & $\begin{array}{l}11.300 \\
(8.353)\end{array}$ \\
\hline $\mathrm{N}$ & 8070 & 2340 & 5730 & 1339 \\
\hline
\end{tabular}


Figure 1: Distribution of Years of US Migration Experience

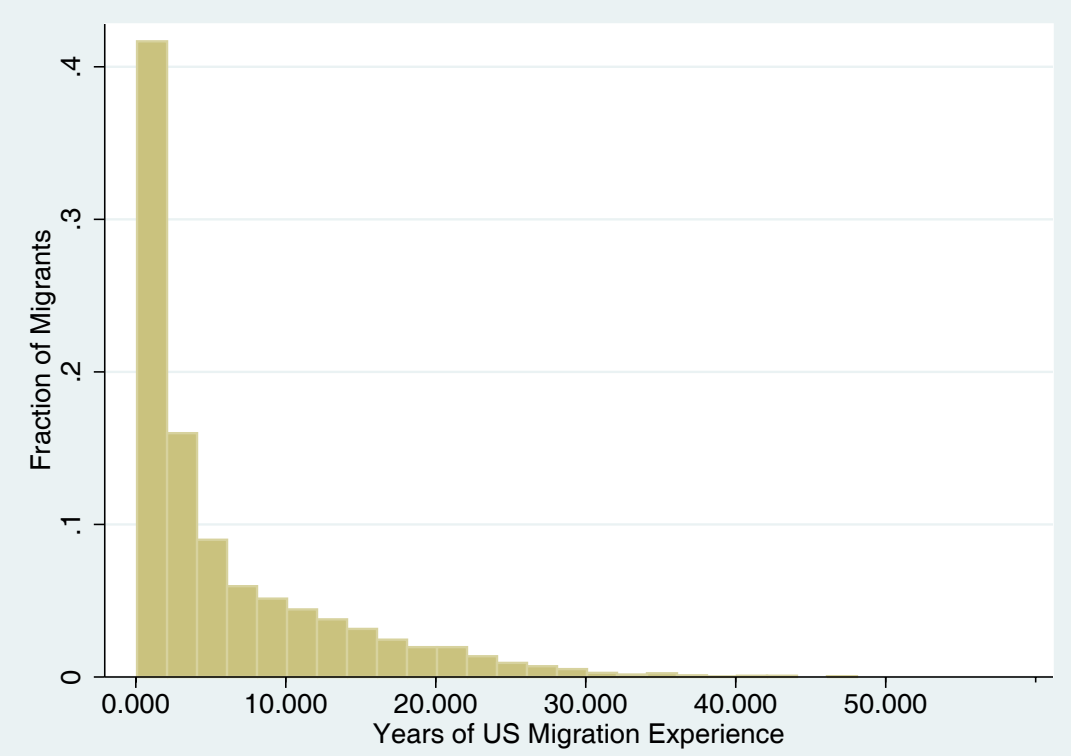

The distribution of total years of migration experience in the United States among the 3679 individuals with migration experience in the total sample. 
Figure 2: Distribution of the Age at First Migration

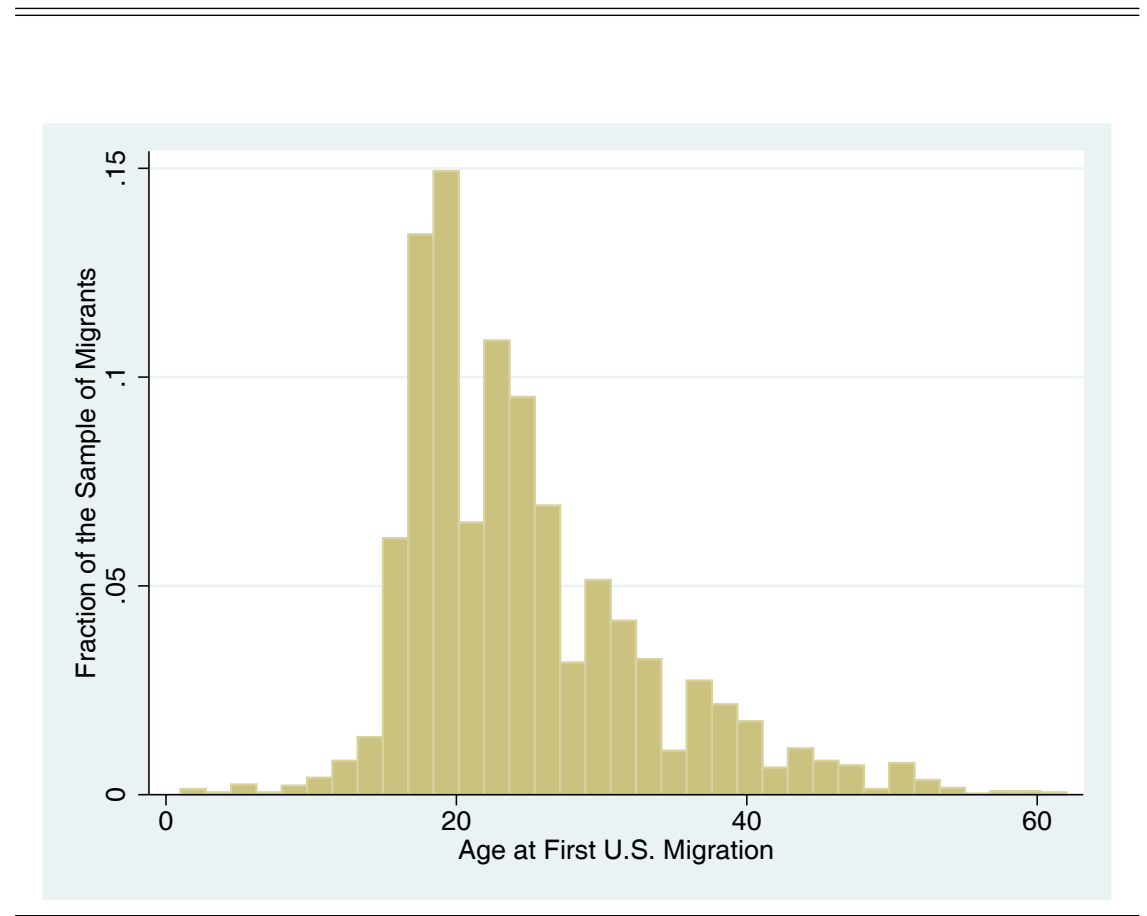

The histogram of age at first migration for the 3696 migrants in the sample, pooling both return migrants and those observed in the United States. 
Figure 3: Smoothed State-Specific Labor Market Shocks Estimated from CPS Data

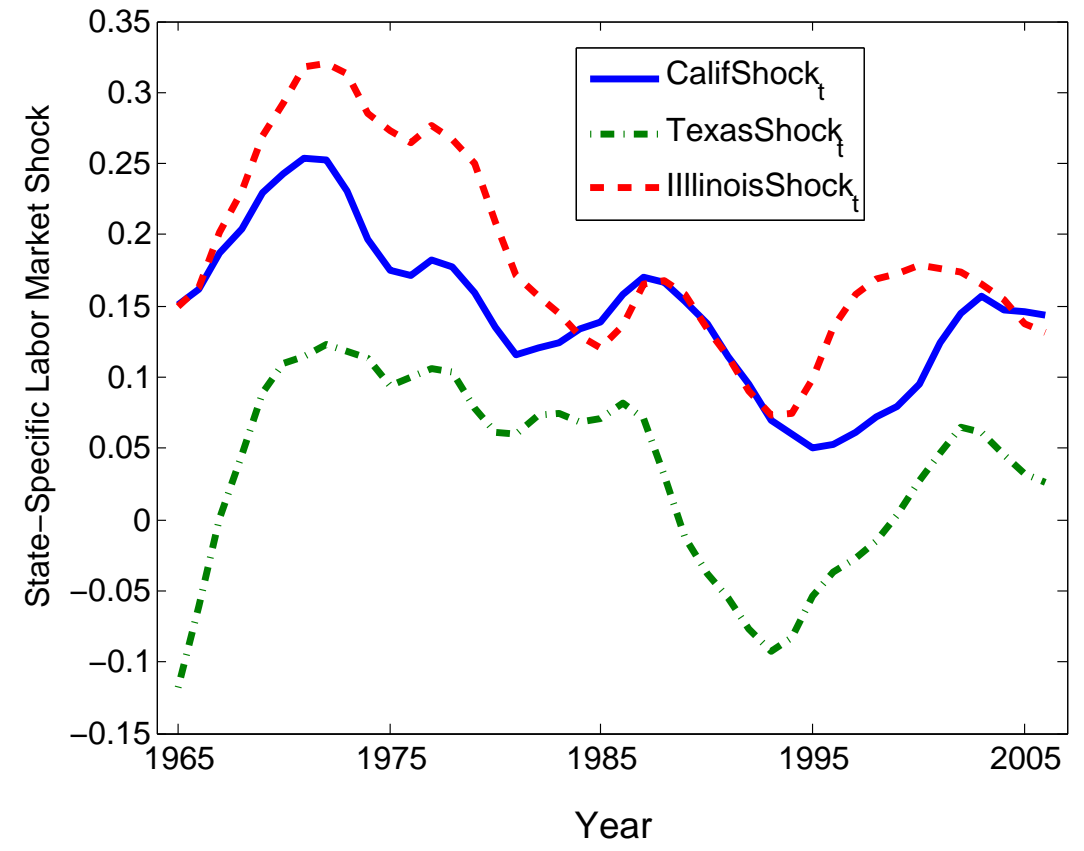


Table 2: OLS regression results for complete sample. Dep. Variable: Log Earnings

\begin{tabular}{llllll}
\hline \hline & $(1)$ & $(2)$ & $(3)$ & $(4)$ & $(5)$ \\
\hline MexExp & $0.007^{* * *}$ & $0.007^{* * *}$ & $0.010^{* * *}$ & $0.009^{* * *}$ & $0.010^{* * *}$ \\
& $(0.003)$ & $(0.003)$ & $(0.003)$ & $(0.003)$ & $(0.003)$ \\
MexExp ${ }^{2} / 100$ & $-0.012^{* * *}$ & $-0.012^{* * *}$ & $-0.015^{* * *}$ & $-0.014^{* * *}$ & $-0.016^{* * *}$ \\
& $(0.005)$ & $(0.005)$ & $(0.005)$ & $(0.005)$ & $(0.005)$ \\
Education & $0.057^{* * *}$ & $0.058^{* * *}$ & $0.059^{* * *}$ & $0.058^{* * *}$ & $0.059^{* * *}$ \\
& $(0.002)$ & $(0.002)$ & $(0.002)$ & $(0.002)$ & $(0.002)$ \\
Married & $0.081^{* * *}$ & $0.080^{* * *}$ & $0.073^{* * *}$ & $0.078^{* * *}$ & $0.075^{* * *}$ \\
& $(0.024)$ & $(0.024)$ & $(0.024)$ & $(0.024)$ & $(0.024)$ \\
US Migration & & 0.017 & & & \\
US Mig. Years & & $(0.018)$ & & & $0.022^{* * *}$ \\
& & & $(0.004)$ & & $0.021^{* * *}$ \\
Less than 1 Years of Mig. Experience & & & & $-0.057^{* * *}$ & $-0.062^{* * *}$ \\
& & & & $(0.024)$ & $(0.024)$ \\
1-2 Years of Mig. Experience & & & & -0.003 & \\
2-3 Years of Mig. Experience & & & & $0.031)$ & \\
More than 3 Years of Mig. Experience & & & & 0.052 & \\
N & & & & $0.038)$ & \\
$R^{2}$ & 8070 & 8070 & 8070 & 8070 & 8070 \\
\hline
\end{tabular}

The sample for each set of results pools observations from the 198\%-2007 surveys. Robust standard errors in parentheses. All regressions include community fixed effects (not reported) The variable MexExp measures accumulated years of work experience in the Mexican labor market. The symbols ${ }^{*},{ }^{* *}$, and ${ }^{* * *}$ indicate statistical significance at the .1, .05, and .01 levels, respectively. 
Table 3: Selection Model Estimation Results

\begin{tabular}{llll}
\hline \hline & Wage equation & US Migration Years & Selection Equation \\
\hline US Migration Years & $0.099^{* * *}$ & & \\
MexExp & $(0.036)$ & & $0.242^{* * *}$ \\
& 0.005 & $0.041^{*}$ & $(0.010)$ \\
MexExp $/ 100$ & $(0.009)$ & $(0.021)$ & $-0.286^{* * *}$ \\
& 0.000 & $-0.283^{* * *}$ & $(0.028)$ \\
Education (years) & $(0.019)$ & $(0.037)$ & $0.056^{* * *}$ \\
& $0.061^{* * *}$ & $-0.045^{* * *}$ & $(0.007)$ \\
Married & $(0.003)$ & $(0.007)$ & 0.055 \\
& 0.050 & $0.326^{* * *}$ & $(0.080)$ \\
US Shock Age 15 & $(0.033)$ & $(0.084)$ & $-4.515^{* * *}$ \\
& & $6.032^{* * *}$ & $(1.073)$ \\
US Shock Age 17 & & $(1.094)$ & -1.307 \\
& & $-4.171^{* * *}$ & $(1.618)$ \\
US Shock Age 19 & & $(1.604)$ & $-9.099^{* * *}$ \\
& & $14.796^{* * *}$ & $(1.195)$ \\
$\hat{\lambda}$ (Heckman Lambda) & -0.328 & $(1.421)$ & \\
Earnings Observations & $(0.248)$ & $4.660^{* * *}$ & 5003 \\
Selection Observations & 5954 & $(0.230)$ & 5954 \\
Hansen's J Statistic & 2.989 & 5003 & \\
Degrees of Freedom & 2 & 5954 & \\
F-test stat (Mig. Years) & & & \\
Degrees of Freedom & & $47.95^{* * *}$ & \\
\hline
\end{tabular}

The sample for each set of results pools observations from the 1987-2007 surveys. All regressions include constants and community fixed effects (not reported) The variable MexExp measures accumulated years of work experience in the Mexican labor market. The symbols ${ }^{*},{ }^{* *}$, and ${ }^{* * *}$ indicate statistical significance at the $.1, .05$, and .01 levels, respectively. 
Table 4: Selection Model Estimation Results for Subsamples

\begin{tabular}{|c|c|c|}
\hline & 1987-1996 & 1997-2007 \\
\hline \multirow[t]{2}{*}{ US Migration Years } & $0.117^{*}$ & $0.091^{* *}$ \\
\hline & $(0.067)$ & $(0.043)$ \\
\hline \multirow[t]{2}{*}{ MexExp } & -0.016 & 0.002 \\
\hline & $(0.029)$ & $(0.010)$ \\
\hline \multirow[t]{2}{*}{ MexExp ${ }^{2} / 100$} & 0.079 & 0.001 \\
\hline & $(0.076)$ & $(0.020)$ \\
\hline \multirow[t]{2}{*}{ Education (years) } & $0.063^{* * *}$ & $0.058 * * *$ \\
\hline & $(0.004)$ & $(0.003)$ \\
\hline \multirow[t]{2}{*}{ Married } & 0.083 & 0.048 \\
\hline & $(0.095)$ & $(0.031)$ \\
\hline \multirow[t]{2}{*}{$\widehat{\lambda}$ (Heckman Lambda) } & -0.417 & -0.398 \\
\hline & $(0.531)$ & $(0.309)$ \\
\hline Earnings Observations & 1974 & 2962 \\
\hline Selection Observations & 2399 & 3422 \\
\hline Hansen's J Statistic & 0.240 & $7.556^{* *}$ \\
\hline Degrees of Freedom & 2 & 2 \\
\hline F-test stat (Mig. Years) & $16.92^{* * *}$ & $27.48^{* * *}$ \\
\hline Degrees of Freedom & $(3,1928)$ & $(3,2900)$ \\
\hline \multicolumn{3}{|c|}{$\begin{array}{l}\text { All regressions include constants and community fixed effects (not } \\
\text { reported) The variable MexExp measures accumulated years of } \\
\text { work experience in the Mexican labor market. The symbols *, **, } \\
\text { and *** indicate statistical significance at the } .1, .05 \text {, and } .01 \text { lev- } \\
\text { els, respectively. }\end{array}$} \\
\hline
\end{tabular}


Table 5: Summary Statistics of Occupations and Business Ownership

\begin{tabular}{|c|c|c|c|c|c|c|}
\hline & \multicolumn{2}{|c|}{ Full Mexican Sample } & \multicolumn{2}{|c|}{ Return Migrants } & \multicolumn{2}{|c|}{ " Non-Migrants } \\
\hline & Fraction & $\mathrm{N}$ & Fraction & $\mathrm{N}$ & Fraction & $\mathrm{N}$ \\
\hline Occ: Other & 0.369 & 8070 & 0.286 & 2340 & 0.403 & 5730 \\
\hline Occ: Agriculture & 0.268 & 8070 & 0.331 & 2340 & 0.242 & 5730 \\
\hline $\begin{array}{l}\text { Occ: Manufacturing } \\
\text { Supervisors }\end{array}$ & 0.014 & 8070 & 0.011 & 2340 & 0.014 & 5730 \\
\hline $\begin{array}{l}\text { Occ: Manufacturing } \\
\text { Skilled }\end{array}$ & 0.198 & 8070 & 0.209 & 2340 & 0.194 & 5730 \\
\hline $\begin{array}{l}\text { Occ: Manufacturing } \\
\text { Operators }\end{array}$ & 0.014 & 8070 & 0.011 & 2340 & 0.016 & 5730 \\
\hline $\begin{array}{l}\text { Occ: Manufacturing } \\
\text { Unskilled }\end{array}$ & 0.105 & 8070 & 0.113 & 2340 & 0.102 & 5730 \\
\hline Occ: Services & 0.032 & 8070 & 0.038 & 2340 & 0.029 & 5730 \\
\hline Own Business & 0.257 & 8070 & 0.279 & 2340 & 0.247 & 5730 \\
\hline $\begin{array}{l}\text { Own Business } \\
\text { Before Migration }\end{array}$ & & & 0.067 & 1875 & & \\
\hline $\begin{array}{l}\text { Own Business } \\
\text { After Migration }\end{array}$ & & & 0.310 & 1875 & & \\
\hline
\end{tabular}



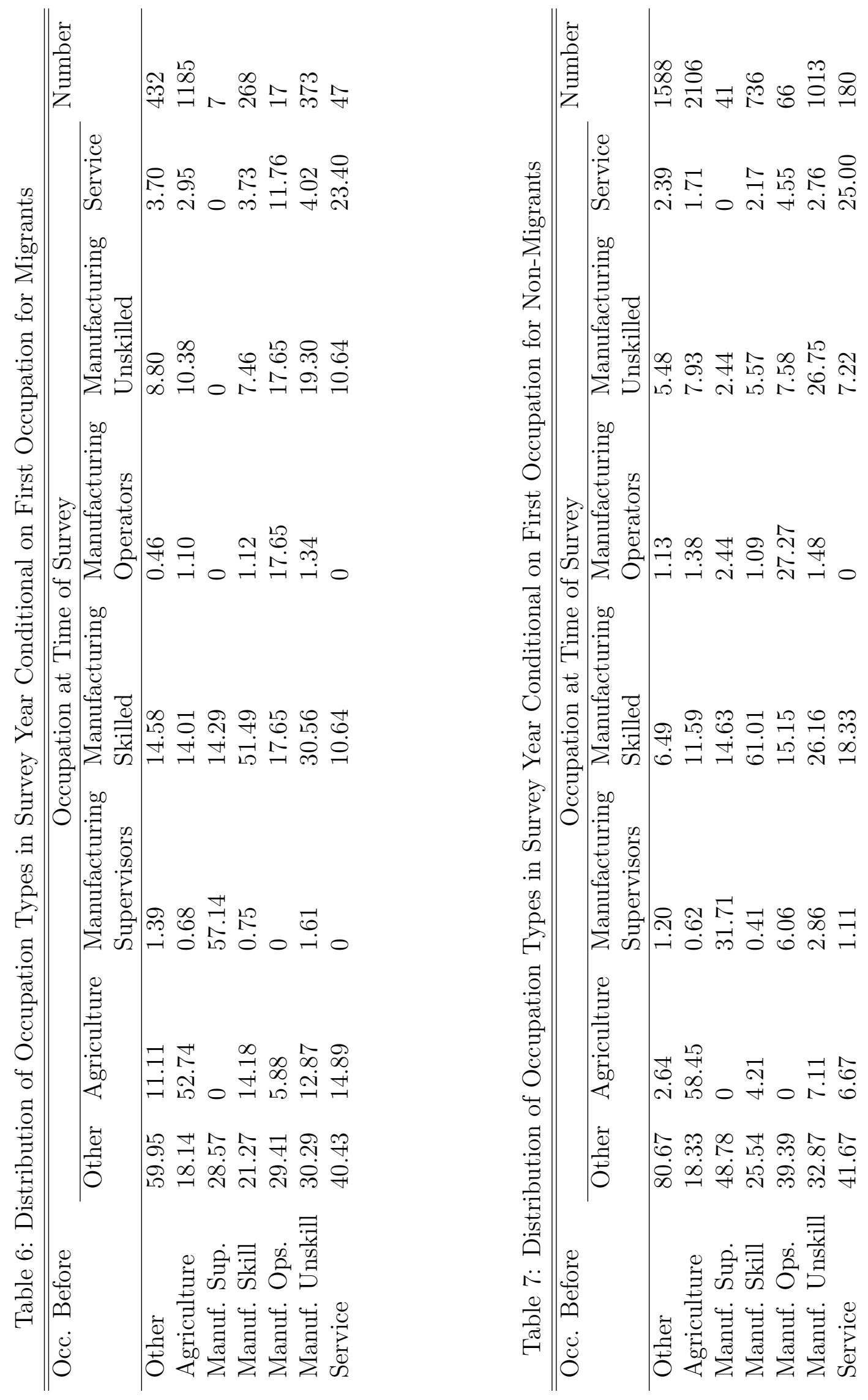
Table 8: Supplementary OLS Regressions on the Effect of Occupation and Business Ownership

\begin{tabular}{|c|c|c|c|c|}
\hline \multirow{2}{*}{ US Migration Years } & (1) & $(2)$ & $(3)$ & $(4)$ \\
\hline & & $\begin{array}{l}0.022^{* * *} \\
(0.004)\end{array}$ & & $\begin{array}{l}0.007^{*} \\
(0.004)\end{array}$ \\
\hline $\begin{array}{l}\text { Relevant U.S. } \\
\text { Experience }\end{array}$ & & & $\begin{array}{l}0.043^{* * *} \\
(0.007)\end{array}$ & $\begin{array}{l}0.036^{* * *} \\
(0.008)\end{array}$ \\
\hline US Mig. Years (doc.) & $\begin{array}{l}0.033^{* * *} \\
(0.007)\end{array}$ & & & \\
\hline US Mig. Years (undoc.) & $\begin{array}{l}0.016^{* * *} \\
(0.004)\end{array}$ & & & \\
\hline MexExp & $\begin{array}{l}0.010^{* * *} \\
(0.003)\end{array}$ & $\begin{array}{l}0.007^{* * *} \\
(0.002)\end{array}$ & $\begin{array}{l}0.007^{* * *} \\
(0.002)\end{array}$ & $\begin{array}{l}0.007 * * * \\
(0.002)\end{array}$ \\
\hline MexExp ${ }^{2} / 100$ & $\begin{array}{l}-0.016^{* * *} \\
(0.005)\end{array}$ & $\begin{array}{l}-0.009^{* *} \\
(0.005)\end{array}$ & $\begin{array}{l}-0.010^{* *} \\
(0.005)\end{array}$ & $\begin{array}{l}-0.011^{* *} \\
(0.005)\end{array}$ \\
\hline Education & $\begin{array}{l}0.059 * * * \\
(0.002)\end{array}$ & $\begin{array}{l}0.050 * * * \\
(0.002)\end{array}$ & $\begin{array}{l}0.049^{* * *} \\
(0.002)\end{array}$ & $\begin{array}{l}0.049^{* * *} \\
(0.002)\end{array}$ \\
\hline Married & $\begin{array}{l}0.074^{* * *} \\
(0.024)\end{array}$ & $\begin{array}{l}0.066^{* * *} \\
(0.023)\end{array}$ & $\begin{array}{l}0.067^{* * *} \\
(0.023)\end{array}$ & $\begin{array}{l}0.066^{* * *} \\
(0.023)\end{array}$ \\
\hline Occ: Agriculture & & $\begin{array}{l}-0.327^{* * *} \\
(0.023)\end{array}$ & $\begin{array}{l}-0.352^{* * *} \\
(0.023)\end{array}$ & $\begin{array}{l}-0.350^{* * *} \\
(0.023)\end{array}$ \\
\hline Occ: Supervisors & & $\begin{array}{l}0.129 * * * \\
(0.047)\end{array}$ & $\begin{array}{l}0.131^{* * *} \\
(0.048)\end{array}$ & $\begin{array}{l}0.129^{* * *} \\
(0.047)\end{array}$ \\
\hline Occ: Skilled & & $\begin{array}{l}-0.039^{*} \\
(0.021)\end{array}$ & $\begin{array}{l}-0.048^{* *} \\
(0.021)\end{array}$ & $\begin{array}{l}-0.046^{* *} \\
(0.021)\end{array}$ \\
\hline Occ: Operators & & $\begin{array}{l}-0.144^{* *} \\
(0.059)\end{array}$ & $\begin{array}{l}-0.146^{* *} \\
(0.059)\end{array}$ & $\begin{array}{l}-0.144^{* *} \\
(0.059)\end{array}$ \\
\hline Occ: Unskilled & & $\begin{array}{l}-0.140^{* * *} \\
(0.027)\end{array}$ & $\begin{array}{l}-0.153^{* * *} \\
(0.027)\end{array}$ & $\begin{array}{l}-0.151^{* * *} \\
(0.027)\end{array}$ \\
\hline Occ: Service & & $\begin{array}{l}-0.076^{*} \\
(0.041)\end{array}$ & $\begin{array}{l}-0.084^{* *} \\
(0.041)\end{array}$ & $\begin{array}{l}-0.084^{* *} \\
(0.041)\end{array}$ \\
\hline Business Owner & & $\begin{array}{l}0.074^{* * *} \\
(0.019)\end{array}$ & $\begin{array}{l}0.081^{* * *} \\
(0.018)\end{array}$ & $\begin{array}{l}0.078 * * * \\
(0.018)\end{array}$ \\
\hline $\mathrm{N}$ & 8070 & 8070 & 8070 & 8070 \\
\hline$R^{2}$ & 0.309 & 0.333 & 0.336 & 0.336 \\
\hline
\end{tabular}

Robust standard errors in parentheses. All regressions include community fixed effects (not reported). The variable Revlevant U.S. Experience measures the number of years spent in the United States during which the individual was employed in the same industry in which they are currently employed in Mexico. The variable MexExp measures accumulated years of work experience in the Mexican labor market. The symbols *, **, and ${ }^{* * *}$ indicate statistical significance at the $.1, .05$, and .01 levels, respectively. 


\section{References}

Bellemare, Charles, "A life-cycle model of outmigration and economic assimilation of immigrants in Germany," The European Economic Review, 2007, 51, 553576.

Borjas, George J. and Brent Bratsberg, "Who Leaves? The Outmigration of the Foreign-Born," The Review of Economics and Statistics, 1996, 78 (1), 165-176.

Co, Catherine Y., Ira N. Gang, and Myeong-Su Yun, "Returns to returning," Journal of Population Economics, 2000, 13, 57-79.

Colussi, Aldo, "Migrants' Networks: An Estimable Model of Illegal Mexican Migration," January 2006. Unpublished Working Paper.

de Coulon, Augustin and Matloob Piracha, "Self-selection and the performance of return migrants: the source country perspective," Journal of Population Economics, 2005, 18,779807 .

Docquier, Frederic and Hillel Rapoport, "Skilled Migration: The Perspective of Developing Countries," in J. Bhagwati and G. Hanson, eds., Skilled Migration: Prospects, Problems and Policy, New York: The Russel Sage Foundation, forthcoming.

Durand, Jorge, Emilio A. Parrado, and Douglas S. Massey, "Migradollars and Development: A Reconsideration of the Mexican Case," International Migration Review, 1996, 30, 423-444.

Dustmann, Christian and Oliver Kirchkamp, "The optimal migration duration and activity choice after re-migration," Journal of Development Economics, 2002, 67, 351372.

_ and Yoram Weiss, "Return Migration: Theory and Empirical Evidence from the UK," British Journal of Industrial Relations, June 2007, 45 (2), 236256. 
Hansen, Lars Peter, "Large Sample Properties of Generalized Method of Moments Estimators," Econometrica, 1982, 50 (4), 1029 - 1054.

Harris, John R. and Michael P. Todaro, "Migration, Unemployment, and Development: A Two-Sector Analysis," The American Economic Review, 1970, 60, 126-142.

Iara, Anna, "Skill Diffusion by Temporary Migration? Returns to Western European Working Experience in the EU Accession Countries," 2006. Global Development Network Working Paper.

Lacuesta, Aitor, "Emigration and Human Capital: Who Leaves, Who Comes Back, and What Difference Does it Make?," 2006. Banco De Espana Working Paper No. 0620.

Lucas, Robert E.B., "Internal Migration in Developing Countries," Handbook of Population and Family Economics, Volume II, 1997, pp. 721-798.

Massey, Douglas S., Jorge Durand, and Nolan J. Malone, Beyond Smoke and Mirrors: Mexican Immigration in an Era of Economic Integration, Russell Sage Foundation Publications, 2003.

Meijer, Erik and Tom Wansbeek, "The Sample Selection Model from a Method of Moments Perspective," Econometric Reviews, 2007, pp. 25-51.

Mincer, Jacob, Schooling, Experience, and Earnings, National Bureau of Economic Research, 1974.

Newey, Whitney K. and Daniel McFadden, "Large Sample Estimation and Hypothesis Testing," Handbook of Econometrics, Volume IV, 1994, pp. 2113-2245. 
Rapoport, Hillel and Frederic Docquier, "The Economics of Migrants Remittances," in S.-C. Kolm and J. Mercier Ythier, eds., Handbook of the Economics of Giving, Altruism and Reciprocity, Vol. 2, Amsterdam: North Holland, 2007, chapter 17.

Santos, Manon Domingues Dos and Fabien Postel-Vinay, "Migration as a source of growth: The perspective of a developing country," Journal of Population Economics, 2003, 16, 161-175.

Stock, James H., Jonathan H. Wright, and Motohiro Yogo, "A Survey of Weak Instruments and Weak Identification in Generalized Methods of Moments," Journal of Business and Economic Statistics, 2002, 20 (4), 518-529.

Thom, Kevin, "Repeated Circular Migration: Theory and Evidence," 2008. Working Paper.

Woodruff, Christopher and Rene Zenteno, "Migration networks and microenterprises in Mexico," The Journal of Development Economics, 2007, 82, 509-528.

Zahniser, Steven S., Mexican migration to the United States : the role of migration networks and human capital accumulation, New York: Garland Pub, 1999. 


\section{Discussion Paper Series}

Mannheim Research Institute for the Economics of Aging, Universität Mannheim

To order copies, please direct your request to the author of the title in question.

\begin{tabular}{|c|c|c|c|}
\hline Nr. & Autoren & Titel & Jahr \\
\hline $170-08$ & Jürgen Maurer & $\begin{array}{l}\text { Who has a clue to preventing the flu? } \\
\text { Unravelling supply and demand effects on the } \\
\text { take-up of influenza vaccinations }\end{array}$ & 08 \\
\hline $171-08$ & $\begin{array}{l}\text { Johannes Binswanger } \\
\text { Daniel Schunk }\end{array}$ & $\begin{array}{l}\text { What Is an Adequate Standard of Living } \\
\text { during Retirement? }\end{array}$ & 08 \\
\hline $172-08$ & $\begin{array}{l}\text { Mathis Schröder } \\
\text { Axel Börsch-Supan }\end{array}$ & Retrospective Data Collection in Europe & 08 \\
\hline $173-09$ & Michael Ziegelmeyer & $\begin{array}{l}\text { Documentation of the logical imputation using } \\
\text { the panel structure of the 2003-2008 German } \\
\text { SAVE Survey }\end{array}$ & 09 \\
\hline $174-09$ & $\begin{array}{l}\text { Axel Börsch-Supan, } \\
\text { Tabea Bucher-Koenen, } \\
\text { Martin Gasche und } \\
\text { Christina Benita Wilke }\end{array}$ & $\begin{array}{l}\text { Ein einheitliches Rentensystem für } \\
\text { Ost- und Westdeutschland - } \\
\text { Simulationsrechnungen zum Reformvorschlag } \\
\text { des Sachverständigenrates }\end{array}$ & 09 \\
\hline $175-09$ & $\begin{array}{l}\text { Steffen Reinhold, } \\
\text { Hendrik Jürges }\end{array}$ & Parental Income and Child Health in Germany & 09 \\
\hline $176-09$ & $\begin{array}{l}\text { Karsten Hank, Marcel } \\
\text { Erlinghagen }\end{array}$ & $\begin{array}{l}\text { Perceptions of Job Security in Europe's Ageing } \\
\text { Workforce }\end{array}$ & 09 \\
\hline $177-09$ & $\begin{array}{l}\text { Hendrik Jürges, } \\
\text { Karsten Hank, }\end{array}$ & $\begin{array}{l}\text { The Last Year of Life in Europe: Initial findings } \\
\text { from the SHARE study }\end{array}$ & 09 \\
\hline $178-09$ & Steffen Reinhold & $\begin{array}{l}\text { Reassessing the Link between Premarital } \\
\text { Cohabitation and Marital Instability }\end{array}$ & 09 \\
\hline $179-09$ & $\begin{array}{l}\text { Alexander Ludwig, } \\
\text { Edgar Vogel }\end{array}$ & $\begin{array}{l}\text { Mortality, Fertility, Education and Capital } \\
\text { Accumulation in a simple OLG Economy }\end{array}$ & 09 \\
\hline $180-09$ & Edgar Vogel & $\begin{array}{l}\text { From Malthus to Modern Growth: Child Labor, } \\
\text { Schooling and Human Capital }\end{array}$ & 09 \\
\hline $181-09$ & $\begin{array}{l}\text { Steffen Reinhold, } \\
\text { Hendrik Jürges }\end{array}$ & $\begin{array}{l}\text { Secondary School Fees and the Causal Effect } \\
\text { of Schooling on Health Behaviour }\end{array}$ & 09 \\
\hline $182-09$ & $\begin{array}{l}\text { Steffen Reinhold, } \\
\text { Kevin Thom }\end{array}$ & $\begin{array}{l}\text { Temporary Migration and Skill Upgrading: } \\
\text { Evidence from Mexican Migrants }\end{array}$ & 09 \\
\hline
\end{tabular}

